\title{
Insignificant Stories: The Burden of Feeling Unhinged and Uncanny in Detours of Teaching, Learning, and Reading
}

David Lewkowich

McGill University

\section{Author Note}

David Lewkowich, McGill University, Faculty of Education, Department of Integrated Studies in Education

Correspondence concerning this article should be addressed to David Lewkowich, E-mail: david.lewkowich@mail.mcgill.ca

\begin{abstract}
By setting foot back in the space of school, teachers stage a return that is necessarily uncanny, encountering a strangeness that is nonetheless known, intimate, and familiar. Through positing the notion of a burden of feeling, this article theorizes the psychoanalytic concept of the uncanny as a way to think through the narrative difficulties inherent in interpreting the variously psychical, historical, and sensual influences of our personal educational experiences. Since we are here dealing - as in literature - with the inescapable singularity of experience, I intersperse a number of my own memories of teaching and schooling throughout this article, in the hopes of productively framing our understanding of educational spaces - spaces of reading and interpretation always-as necessarily unhinged and uncanny. In this framing, I also argue for the importance of telling insignificant stories, and that rather than insinuating a method that looks to the obviously memorable and notable, I propose a practice of looking instead to the trivial and the typically forgotten. As a methodological practice, this article employs-in parta multimodal strategy of strange juxtaposition, drawing attention to the spaces between words, and upsetting the framings of traditional narrative. The images that are interspersed throughout this piece suggest the pursual of a reading that lets itself stray, and that requests of the reader an imaginative and a collaborative interpretive practice.
\end{abstract}

Keywords: teaching; education and psychoanalysis; teacher identity; the uncanny; educational memories 


\section{Insignificant Stories: The Burden of Feeling Unhinged and Uncanny in Detours of Teaching, Learning, and Reading}

"Words had always left long bloody marks wherever they fell." -Knut Hamsun, Hunger (1890/2008, p. 120)

I am going to start off this article with a detour (and to be fair, it is not the only one I will pursue), which I know may seem a strange place to begin, but sometimes by starting theoretically out of place, we work our way into the folds of a bloodier space, where the text leaves its entrails dripping and strewed, readable through its very vulnerability; a body with its organs exposed is a body that is literally fuller than full. I am here gesturing

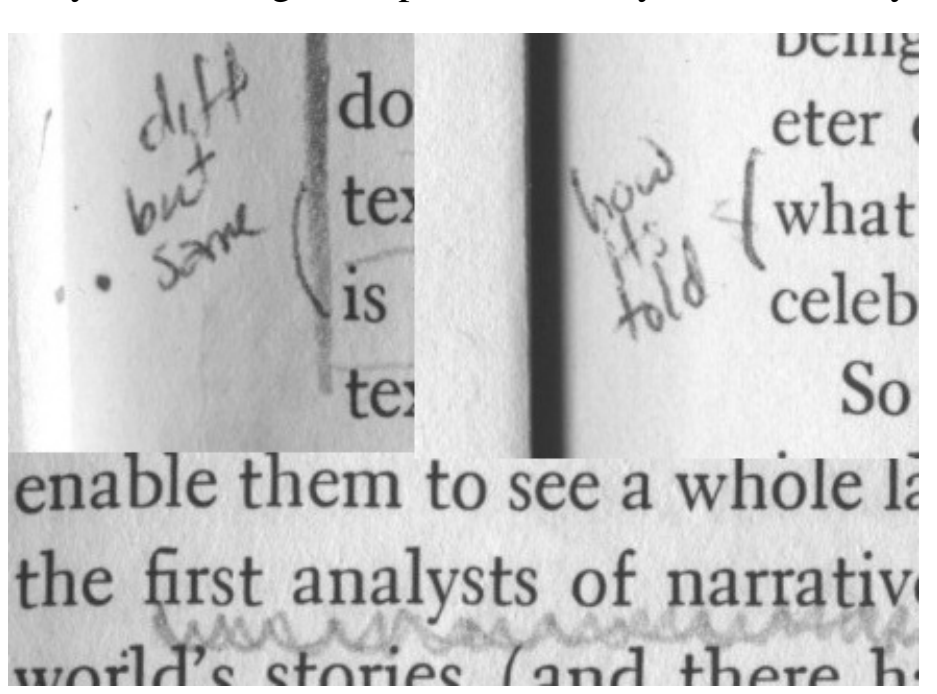
to Lacan's (1991) cryptic methodological turn, which he took up in his discussion of Freud's (1919/2003) concept of the ego; "It is from this long way off," he has written, "that we will start in order to return back towards the centre —which will bring us back to the long way" (p. 3). The method of writing I adopt in this article, which explores the psychoanalytic concept of the uncanny in spaces of teaching and reading, is therefore one of circuitous reasoning (which obviously resembles a kind of nonsense), but since the uncanny itself functions to effect a distortion of memory, circuitousness is certainly an apt path to follow.

From passage to passage, I am taking up tangential reasoning in an overall "embrace of the arbitrary" (Bloomer, 1993, p. 16) and teasing a measure of significance out of the otherwise insignificant (Stiegler, 2009); I am also taking seriously HellerRoazen's (2005) claim that "from one language to another, something always remains, even if no one is left to recall it" (p. 77). As I read it, this is not a claim that concerns only the vagaries of memory, or the shifting of language, though it certainly involves the crossing of such strictures. It is a claim that deals with the world we inhabit, the ways such inhabitancy is forever ghosted, and the reminders that strike us in ways unintended, our past lives that shift through the passage of time.

Through sometimes-contrasting styles of presentation (which are meant to disturb and juxtapose, rather than simply confuse), this article approaches the fields of teaching and reading as inevitably informed by the movable meanings of memory. Each section of this article can thus be read as an individual scene, which, taken together, composes an intricate drama. In defining this endeavour as a partly autobiographical pursuit, ${ }^{1}$ I am here interested in the possibilities that emerge in the creation (and theorization) of what Mitchell, Strong-Wilson, Pithouse, and Allnutt (2011) have referred to as "remembering spaces," and the ways in which such spatial events can serve as imaginative reminders of 
the fact that "the spaces we move through are not neutral" (p. 3). What this lack of neutrality implies is that these spaces are always socially composed, even when such sociality is simply the result of being populated by an other that is our unconscious self (Kristeva, 1991).

In such "remembering spaces," it is also worth keeping in mind that, as Britzman (1998) has succinctly put it, "There is always more to the story," which in relation to the "haunting persistence" of the uncanny, "can be examined only in bits and pieces" (p. 14). It is with this awareness of the fragmented influence of the uncanny on spaces of memory that I suggest a strategy of reading that lets itself stray, and that requests of the reader an imaginative and collaborative interpretive practice. Though I describe the psychoanalytic model of the uncanny at length later on in this article, it is here worth mentioning that an uncanny experience is one in which the past is unintentionally repeated, and where, though what emerges may no doubt bear some unclear resemblance to a past event or encounter, it is also inevitably distorted. That which is uncanny is, therefore, simultaneously familiar and foreign; it is this distorted repetition often causes distress and a feeling of being unhinged.

Though every reading inevitably depends on some degree of collaboration between the reader and text, this article takes up the challenge of multimodality described by Gee (2008), wherein words and images mix to create a scene of inseparable sense that requires "non-linear ways of reading" (King, 2011, p. 74). Through inserting various images in this article, and stylizing the text in more than one way, I am gesturing towards the potential uses of guttering in academic writing. As King (2011) has described this practice of aesthetic presentation in relation to graphic novels, "the gutters (the spaces between panels) lead readers to make connections and establish closure" across a variety of textual forms, which "also allows readers to pause between panels as they make meaning” (p. 71). The gutters are, therefore, a form of interpretive interruption. The gutters themselves may be empty (which like any absence signals a presence), or they may be inscribed with some textual gesture that stands apart fromwhile remaining simultaneously dependent upon-the main part

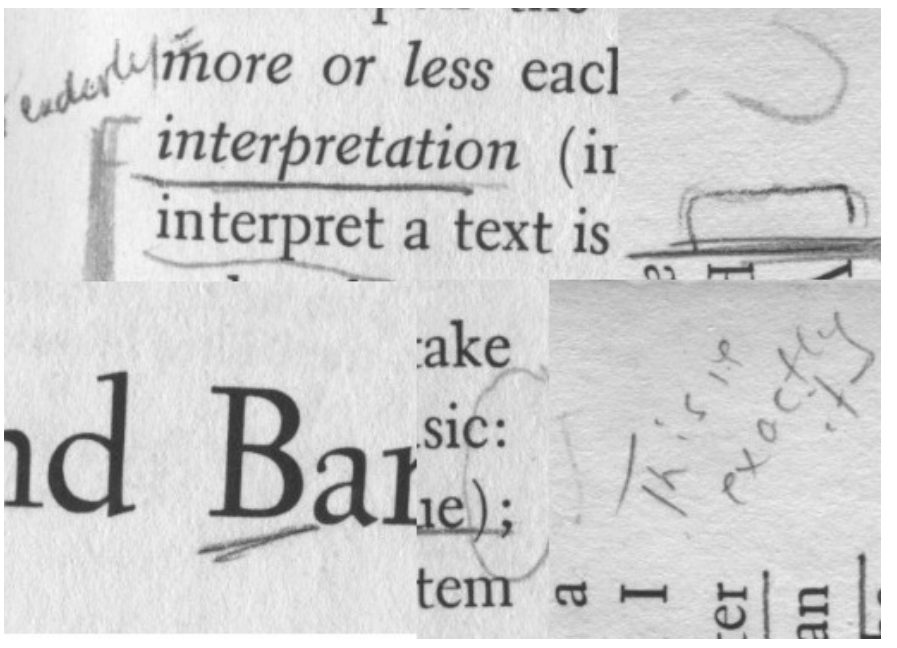
of the textual frame. The point of such a practice is, thus, to proliferate the potential for spaces of meaning in encounters of reading, and to do so in a way that such meaning remains unresolved and necessarily in tension, which is to say, always newly interpretable.

The images that appear in this article, whose particular origins I describe later on, were found in the margins of a library copy of Roland Barthes' $S / Z$ (1974). In my arrangement of these images, which may seem admittedly haphazard (some are 
juxtaposed, some are not, some are legible, some hardly so), I am taking up the challenges of learning in the margins (an always unsure endeavour), described by Irwin and O'Donoghue (2012) in their discussion of relational aesthetics in teacher education. While a text might teach one thing, they ask, what does its margins-and there its traces of past readerships and past desires - teach? How do these margins provoke an oftenunacknowledged uncanniness in reading experience? As Irwin and O’Donoghue (2012) have written, when it comes to readers' responses in encountering the marginal traces of others, "to some this was disruptive; to others this was stimulating" (p. 227). Throughout this piece, I, therefore, use these images as a relational and emotionally provocative space for marginal thinking, well aware that a reader's response can never be predetermined. In the following section, I begin with a literary scene, through which I take up the question of emotional burden in relation to social attachments.

\section{Part 1: The Story of a Dog}

In Niki, The Story of a Dog, Hungarian novelist Tibor Déry (1956/2009) describes the fundamentally vulnerable and emotionally unstable nature of our intersubjective attachments to others. In this novel, Niki, a young, spry fox terrier, playfully connives her way into the lives of Mr. and Mrs. Anksa, who, although fond of animals, are reticent about allowing themselves to become too familiar with this particular creature. Because Mr. Anska's father had only a short time ago been killed in a saturation air raid, and because the couple had just recently lost their son in the Battle of Voronezh during the Second World War, they were initially opposed to the idea of assuming, what Déry calls, a new burden of feeling, which can here be described as an affectively persistent encumbrance that is charged and disposed through human and non-human relations of meaning, interdependency, and reliance. As the author notes, the Anksas "had good reason to know that affection is not only a pleasure for the heart but also a burden which ... may oppress the soul quite as much as it rejoices it” (p. 9). Put simply, the Anksas were well aware that what might bring them joy today, and allow them to mourn their recent losses, would also most certainly bring them a new type of grief tomorrow. It is a fear similar to that described by Kristeva (1991): "I lose my boundaries, I no longer have a container, the memory of experiences ... overwhelm me, I lose my composure” (p. 187). As the Anksas discover, in the presence of others, we cannot help but be emotionally unraveled.

Though Mr. Anksa tried his best to frighten the dog away-he calls her a "dirty, clinging, brute" (p. 18) - the Anksas were powerless under the ferocious influence of Niki's love, what Mr. Anksa describes as "the unfair weapon ... against which I have no defense” (p. 20). They tried not to refer to her by name (as if doing so would be to admit their frailty in the face of love), calling her only "the bitch," "the dog," "the brute," or "the terrier," but as their affection grew, the Anksas took up this burden of feeling with a furious passion that knew no negation; they "would not now have hesitated to spill blood in [her] defense" (p. 86). Despite their initial opposition and resistance, the Anksas were, thus, mutually outdone and undone by that which, in any case, they were powerless against from the start. Such a burden of feeling, though its shape may change, is a weight that we all bear as a consequence of being in the world and of having a history, and as with Niki and the Anksas, even if we do not name it, we are nevertheless forced to carry its load. 
Though the story of the Anksas and their burden may seem far removed from our present concerns, for those interested in theorizing the psychic demands of education, such a process of carrying implies, as noted by Lisa Farley (2009), "the ways in which our educational histories linger, haunt, and shape the pedagogical present” (p. 18). Even though this burden can seem a ruthless structure under which we are all powerless subjects, as even the monkey on our back becomes a gorilla, can we make of it something potentially joyous? Though we are beasts of emotional burden, can we carry this burden well?

\section{Part 2: The Teacher as Reader}

In this article, I approach the position of the teacher as a desiring reader: as interpreter of educational experience, as perambulator through fields of emotional inheritance. Rather than simply a skill to be learned, teaching, in this regard, is "a form of memory" (Farley, 2009, p. 18). There is a burden of feeling that accompanies every educational act, an overabundance of affect whose spectral circulations necessarily motivate unconscious movements of love, hate, authority, and desire. As Adam Phillips (1995) has so bluntly stated, "We are too much for ourselves ... we are ... terrorized by an excess of feeling ... an impossibility of desire” (p. xii). In our efforts to discourage uncertainty (staging oftendisharmonious movements that attempt to pry the present from the clutches of the past, or looking to the world of the past as ruptured apart from that of our own), we, as educators, frequently endeavor to move backwards and forwards in that which can only be called the chronologically perverse - the muddied ontological grammar that inevitably represents education's precarious plotting - and find ourselves stuck in the middle, between facing others and meeting ourselves. As Sara Ahmed (2006a) has noted, however, "this

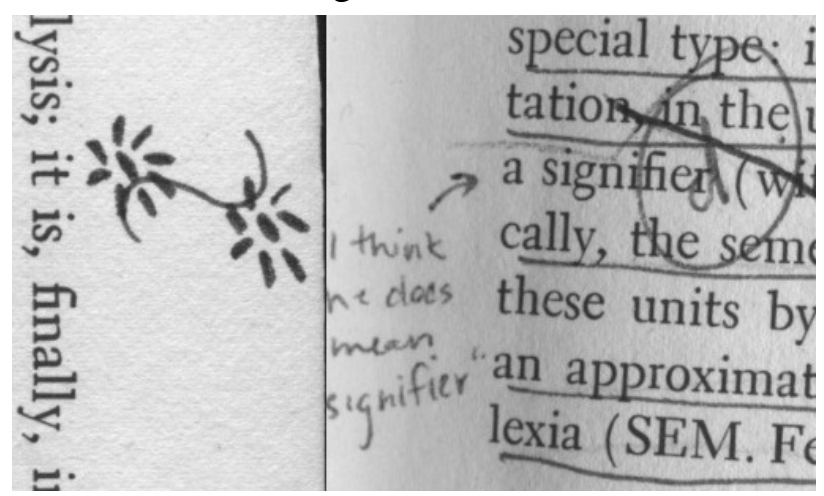
backward glance also means an openness to the future, as the imperfect translation of what is behind us" (p. 570). For the teacher, the past carries the sound that is echoed in the future; and such reverberations, when they remind us of a thing that we feel we know but still cannot name, might well be experienced as confusing, hostile, unspeakable, debilitating, or shattering. By setting foot back in the space of school, we stage a return that is necessarily uncanny, a strangeness that is nonetheless known, intimate, and familiar (Britzman, 1998; Salvio, 2007); we cannot escape its thrall. Through positing the notion of a burden of feeling, this article theorizes the psychoanalytic concept of the uncanny as a way to think through the narrative difficulties inherent in effectively interpreting the variously psychical and historical influences of our personal educational experiences. I, thus, intersperse in the pages that follow a number of my memories of teaching and schooling (and being schooled), in the hopes of productively framing our understanding of educational spaces - spaces of reading and interpretation always_as necessarily unhinged and uncanny. 
For Freud (1919/2003), the uncanny, which in its original German-Das Unheimliche - translates literally as "the unhomely," "belongs to the realm of the frightening, of what evokes fear and dread" (p. 123), and "goes back to what was once well known and had long been familiar" (p. 124). It relates to the home as a place of

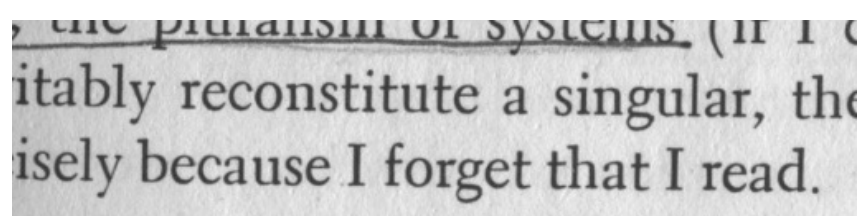

star the text, separating, in the $\mathrm{m}_{\varepsilon}$

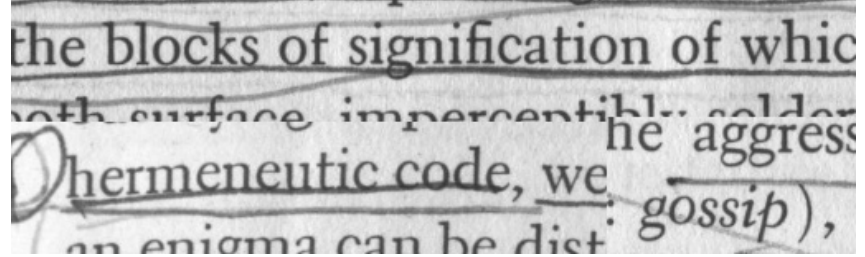
origin and deep familiarity, though, through its negative prefix -un, also indicates the movements and returns of psychical repression; the unknowable nature of an alien force. The uncanny, in the way that it figures a return of the repressed, is most upsetting when encountered as a kind of "unintended repetition" (p. 144) of a past event (or its emotional content), where that which is reencountered, in necessarily distorted form, makes one frightened, regardless of whether the original encounter was frightening or not. Though the uncanny moment is always an encounter with memory, since its content remains disguised, as in a dream, its relation to the original experience that forms the memory is not always recognizable as such. It is this sense of mis-recognition that gives the uncanny its eerie feeling; it wanders as an unknown memory, a lost and forgotten object, and an abandoned part of one's self. Love is a common thing, as is hate, as is vulnerability and frailty in loving relations. For teachers, the helplessness experienced as a student reappears in the helplessness experienced in educating others, which itself reemerges in the helplessness of one's own students, whether real or imagined - a haunting cycle of misidentification that lurks beneath the surface of educational experience.

\section{Part 3: Fantasies of Instinct and Beginnings}

As a new teacher, I was often caught between trying to enact a type of authenticity in the classroom, while also feeling like I had to adopt definitively authoritative attitudes, which

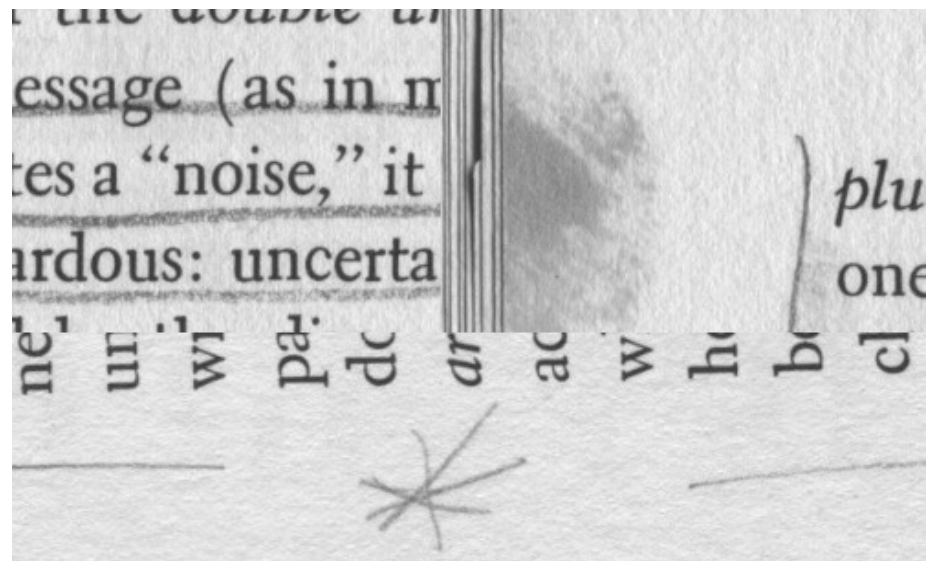
were at odds with who I believed I was, and with whom I believed I wanted to be. I recall my first evening of parent-teacher interviews, which came only a couple weeks after I had been hired. It was like I had hardly a chance to catch my breath, and as Lawrence-Lightfoot (2003) has noted of such occasions, though adults may "come together prepared to focus on the present and the future of the child ... they feel themselves drawn back into their own pasts ... haunted by ancient childhood dramas” (p. 4). Faced with the likely reemergence 
of such a drama, I felt thoroughly unprepared, but trusted that if I kept talking the right words would come, since, if I wanted to be an effective teacher, I presumed that, above all else, I had to put faith in the power of my instincts. I thought to treat things as in sport - "to become smooth and hard as a pebble" (Kristeva, 1991, p. 6)-and like the pitcher on the mound who collapses when he thinks too much about the mechanics of pitching, I would focus instead on trying to stop thinking, on distracting myself as a cure for thought. I would speak from the hip, and from the gut, and from the heart, for to do otherwise would feel untrue, and to feel untrue would feel as a failure. In one moment, though, I was faint, sweaty; I clutched a desk and excused myself from the wide-open eyes staring back at me, sitting in their children's seats. The weight of this terrible responsibility came to me now as a sharp blow. I stared at my face in the bathroom mirror, "archaic senses [awakened] through a burning sensation” (Kristeva, 1991, p. 4), and I was scared of what I saw. I hated the clothes I was wearing, the sweat in my pits and palms, and the cut of my hair. I was running my hands through the cold water, trying to numb whatever it was that had to be numbed.

There is, in the educational encounter, a kaleidoscopic play of past provocations that twists our presumed notions of the correct chronology of time, and mangles our understandings of what Edward Said (1985) has called "the problem of beginnings" (p. 3). For teachers, the idea of coming back to school reminds us of the menacing ways that, as noted by Britzman (2011), "passing time ... leave[s] behind fossils” (p. 53); the surprising reappearance of memories, affects, and past relational strategies, surfacing in the oftenunrecognizable guise of anxieties, defenses, desires, and wishes. The use of the term fossils is here metaphorically apt, for fossils never reemerge exactly as they were, but are invariably altered in texture and form, as paleontologists burden through layers of dust to extract hidden kernels of value, to piece together what was once an object in full that-as memory - has over time since deteriorated. We also have barely an idea which remnants of today will be the fossils of tomorrow. Teacher education is, thus, not a beginning; it always represents a kind of return (Britzman, 2003).

However, if we acknowledge the potential of such returns as corrupted homecomings, we can also, as Peter Brooks (1982) has suggested, talk about returns as "new beginning[s]" (p. 297) as a way to "replay time, so that it may not be lost," and as a narrative practice of self-oscillation that, in reading experience repeatedly anew, contributes to twist and "pervert [the strictures of] time” (p. 299). For Farley (2009), such practices also involve "the possibility of transforming the received, static past ... into a symbolic narrative, in which we can discover how buried conflicts shape the present" (p. 20), and in using our shadows of schooling past, talk out such fossilized conflicts through a pedagogy whose itching must surely be scratched-and whose meaning necessarily "resides in the tensions between the past and the present" (p. 23). It is in replaying our past, and in searching for uncanny and disturbing presences (whether they were felt so 
then or now, and regardless of whether we can name their origins), that we can signal the ways that the emotional scripts of the past persist in the present.

\section{Part 4: Passionate Companions}

The lunchroom is one of those spaces where authority is fragile, precarious, and always susceptible to being hijacked. For the teacher who administers detention in this room after school, there is a strangeness that emerges when spaces like this are used to such contrary ends: eating and discipline, frolic and silence, and friendship and alienation. Since my own memories of lunchrooms are food fights and hot dogs, giggles and gropes, and sizing up fashion and secretive cigarettes, I know well that for encounters in this awkward zone, every word that is spoken implicitly suggests its other, as every action is also a challenge to itself. Things are out of control.

While supervising afterschool detention, I heard a whistle at one end of the cafeteria, followed its tune, then a few seconds later heard another; back where I started

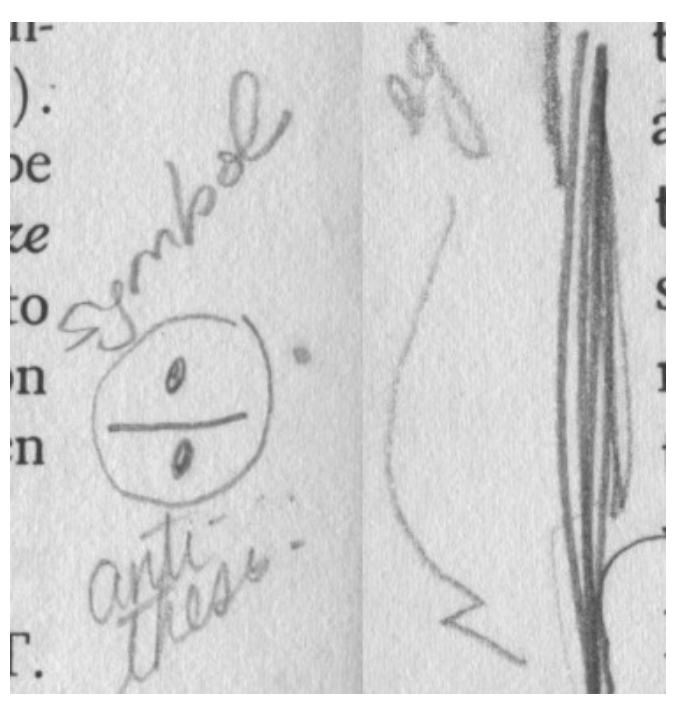
so I moved back again. These were confusing tones, for while whistles may be shrill and severe, they are also seductive and flirtatious. The whistles continued, and when chasing such whistles, I felt like an animal chasing its tail, friskily sweeping itself back and forth, taunting and mocking, provoking and teasing, always just slightly out of reach. The most disorienting thing about this odd situation was the question of who was actually doing the chasing; and if I was the dog and the students my tail, I wanted no less than to chomp down hard. For Kristeva (1991), "strange is the experience of the abyss separating me from the other who shocks me-I do not even perceive him, perhaps he crushes me because I negate him” (p. 187). In the present case, it was difficult to tell who, in fact, was being punished; the students, for acting out against school regulations, or me, in feeling myself to be psychically out of step from, yet also strangely attracted to, the authoritatively inclined demands of my profession. I eventually grew bored, and soon, so did the students, yet I still felt the urge to button their mouths. Unable to connect my desires in teaching with this urge towards hate and this futile chase, I was awkwardly moved and unsettled; not knowing whether to laugh at myself, to tremble in fear, or to froth at the mouth and to rage against others, smashing my fists into walls.

This short and slippery, almost-trivial scene suggests, as Farley (2009) has explained, that there is "something elusive, and unspoken, about history and its passage through the generations" (p. 17); or, to sound a more perilous illustration from Michael Taussig's (1992) reflections on commonplace terror, which point to the ways that banal communications can oftentimes breach their own limits of address:

I am referring to a state of doubleness of social being in which one moves in bursts between somehow accepting the situation as normal, only to be thrown into 
a panic or shocked into disorientation by an event, a rumor, a sight, something said, or not said-something that even while it requires the normal in order to make its impact, destroys it. (p. 18)

While Michael O’Loughlin (2009) has written that his childhood "is irretrievably gone," he has also described how, "My childhood is not a historical remnant. It is very much who I am today. I live my childhood anew each day" (p. 81). What we have here, in O’Loughlin's (2009) description of “inner losses ... [as] perpetual companions” (p. 100), is a purposely contradictory understanding of psychic experience, where "the personal is already a plural condition" (Salvio, 2007, p. 4), and which allows for the fact that even though something inside of us may be forgotten, it nevertheless refuses to disappear. It has, in effect, been displaced, through what Paula Salvio (2007) has beautifully termed "a kind of melancholia that must inhabit an obscure threshold between memory and forgetting” (p. 13). It is when we are brushed brusquely against this threshold that the uncanny emerges in our very self, at the moment that we also witness its undeniably outside appearance; like some kind of passionate, demonic double, moving forever further as we chase it away, remaining always outside our grasp.

\section{Part 5: Teaching as Affected Reading}

Judith Robertson (1994) has spoken of “"the uncanny moment' in research,” as “a moment when [a researcher's] own history seem[s] somehow to repeat itself” (p. 55). "Sometimes," she noted, "I was not sure where I stopped and where the women [I was interviewing] began” (Robertson, 1994, p. 55). As previously stated, the uncanny moment is an encounter with memory whose content remains disguised, so that its relation to the original experience is not immediately identifiable or obvious. While the moments where such feelings arise-say, in the middle of reading a book or teaching a class-might feel strange, the actual relation of the present experience to the hidden memory remains elusive, and it is this elusiveness that gives the experience its quality of strangeness.

As I write this piece, I am serving as one of 12 jurors on a double murder trial, and I often find myself theorizing our interpretative activities as an ideal, possibly an atypical example of the practice of collaborative reading (though the stakes of our interpretive moves are admittedly severe). There are times, though, when I catch myself out, and which feel like a moment of (mis)recognition, where I see that my theorizing is really an attempt to evade the brutal fact of the place in which I am. I can likewise affirm that my life as a child, as an adolescent, and as a student learning to teach, persists in the various anxieties and pleasures I continue to experience as an educator, and which are also often projected onto the actions I read into those who surround me. To talk about a theory of reading in relation to teacher education must also be to admit the fact that, due to our insistent burdens of feeling, readings are always necessarily unstable and multiply mediated: "That every act of interpretation involves the person who is making that interpretation bringing their own emotional [histories] into the equation" (Thurschwell, 2009, p. 39). "When we read," Thurschwell (2009) has noted, "the text affects us; our readings affect the text” (p. 122). The consequences of becoming a teacher are thus confused by the fact that the life of a student is never really finished, and though it folds into that of a teacher, the crease is a muddled space that is hardly discrete. This life of the 
student is not simply a memorable force I can figure and touch and use in my process of coming to know. The moments it contains are also forgotten, tattered remnants "beneath the façade of knowing” (O’Loughlin, 2009, p. 80); repressed images and figures; feelings and vibrations; love and hate that made no sense, and still they do not.

While writing this article, I am also in the midst of my doctoral research, which looks at the experiences of adolescents and preservice teachers in their readings of young adult literature. Because part of this research is in a Montreal-area public high school where I also sometimes work as a substitute teacher, I have often had to negotiate the fact that as my responsibilities change-from student, to researcher, to teacher, and back-it is not always obvious where exactly I am at, or

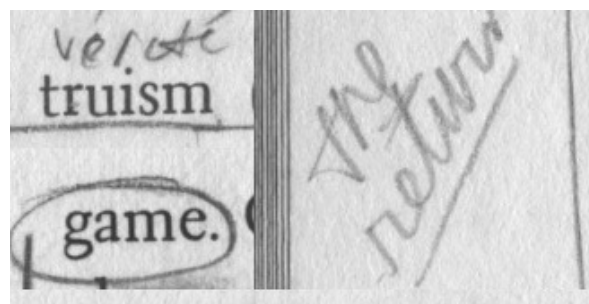
prayuu vy
ity and alk
words for 1
one form 6 XXXII. DELAY in what capacity I am presently assembled. While working as a sub, I recently found myself in the position of being paired with a teacher that I had never met before, and though I briefly explained my situation, he somehow took my description to mean that I was a student teacher. Though I let this innocuous assumption slide, because the uncanny is our burden of feeling in teaching and teacher education, this designation provoked my thoughts to linger in a type of familiar disquiet, which shockingly recalled how the title of student teacher can be coupled with the assumption that one is not real, that one is defined through lack, that one has yet to become an authentic educator. Though the unsure footing of learning to teach was a place I had been to before, since I thought I had already passed through its peculiarities for good, I was made to feel especially strange. Yet, once again and despite my best wishes, I found myself there; the burden remained and I felt out of place. I had been there before, and whatever it was, it was such a weird place my unconscious was saying, “This is not your home! Get home! Now!” The terrible truth, however, is not that there is a voice that is screaming that has no body (and indeed, no scream) - for such uneasiness is not uncommon-but that this seemingly brutal voicing points to a home that does not exist, and to which, as to a figment, one can never return.

\section{Part 6: When Unanswered Challenges Come Stumbling Home}

In relation to the way the uncanny insinuates a division of the threatened subject, Freud (1919/2003) has described how the convictions and beliefs of our "primitive forebears"though we may no longer accept their claims to reality, believing them successfully surmounted-remain in their nature as unanswered challenges to newer, contemporary beliefs. Thus, "as soon as something happens in our lives that seems to confirm these old, discarded beliefs, we experience a sense of the uncanny” (p. 154), as these primitive beliefs vie once again for confirmation and cultural acceptance. In relation to teacher education, such primitive beliefs can be seen, for example, in practices of corporal punishment, and in cultural myths that position the teacher as omnipotent knower, sexless 


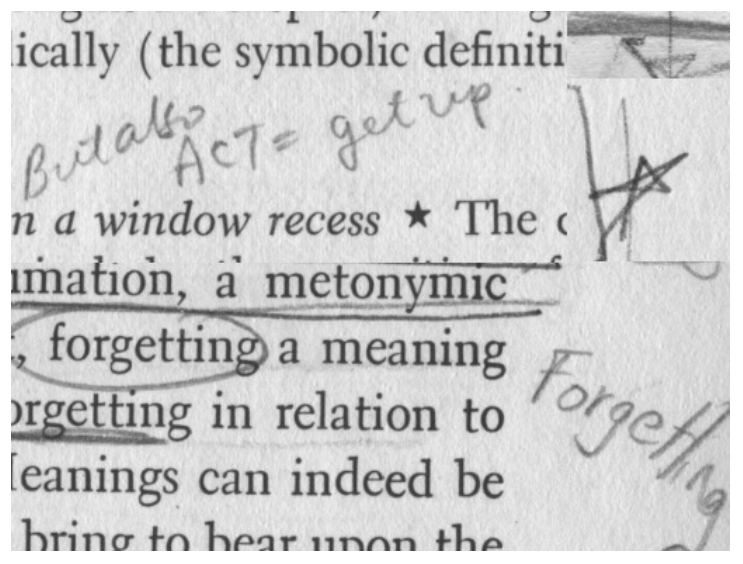

intellect, and unwavering pedagogical enthusiast. As such myths work to place the failure of any pedagogy squarely on the shoulders of the teacher, that everything depends on the teacher (Britzman, 2003), their uncanny appearance approaches most abruptly in moments of educational breakdown-when teachers, no matter how well-intentioned, resist the implications of their student's claims to a knowledge that is different from their own; exasperated, react over-defensively to challenges to their authority; become intolerant to cultural difference; or when, as in my memory above, the idea of a teacher identity appears yet again as menacingly unattainable, the impossible desire for an impossible double.

Such arrivals, which are also always a kind of return, testify to the fact that the burden of feeling in teaching, learning, and teacher education is a species of emotional excess that is constantly seeking a way home. Though it is also an "impossible strangeness" (Robertson, 2001, p. 205) that stubbornly eludes all capture and disintegration, "while it may elude consciousness," as Salvio (2007) has written, "it longs to return, to make its way back" (p. 12), but to a location that can no longer be accessed. No matter how experienced the teacher, there is always a chance that insecurities will erupt. However, this is not to suggest that we educators must constantly live in a state of debilitating fear, and even though this burden of feeling remains as a vestibule, always on the verge of conscious life, and persists as a state of emergency, such is the case for all our existence. At any given moment-in any situation whatsoever-we may become unhinged and unraveled, moved by the other, intimidated by ourselves as by a stranger, as "the normality of the abnormal is shown for what it is" (Taussig, 1992, p. 18). The critical question, as with the story of Niki and the Anksas, is how we choose to name our insecurities, and thus, how we choose to read our attachments to others, while narrating the text of our lived experience. Importantly, however, it must be kept in mind that naming is not surmounting, nor is surmounting a practical objective. Though teaching is here thought as memory, the teacher as reader must take towards memory an approach that makes memory strange. If teachers are to consider themselves as readers of education's emotional variables, it is important to know what it is that we are reading, and how to go about life without ignoring the text, unstable as it may be.

In the following section, I stage the interview as a site of potentially uncanny and dis(en)abling irruption; the mind wanders, not always knowing where it goes, for the wish to stay focused-absolutely absorbed-necessarily remains unattained. We never read every word in a book. We can nod, sigh, laugh, or smile, but we never hear every word that is spoken. Such moments are hard and odd to relate, because it is unclear what position they actually represent - whether an ease, an unease, or a dis-ease-and whether what they do is allow or shut down new forms of insight. These following segments of interview data, which emerged from my dissertation research, were undertaken with senior-level students in a Montreal-area public high school, and revolved around 
questions of adolescence, schooling, and reading. In the left column, I have placed certain wanderings of the mind-the insignificants of interviewing-along with some thoughts about the meanings such wanderings might hold; on the right is the speech I am there to absorb, to critique, and to capture in full. The spaces between, the gutters, the insignificant gaps, are where I like to return to pose questions of the as-if interview: How to read as-if one was not there? How to read as-if one was there in full attention? Though the structure I employ in this section may strike the reader as unexpected, such surprise also begs the question of why the expected, in reading experience, is positioned as such. What do we expect from the expected? In relation to the dynamics of the qualitative interview, this question speaks to the fact that if we are only looking for what we expect, we may be blinded to the unexpected. 


\section{Part 7: Erroring}

It is a strange thing, interviewing in spaces of schooling. Animated voices (quivering, exploding) reverberate down hallways and classrooms, empty shells with Nystrom relief maps, hardened gum on the desk's underside, unsharpened pencils and slants of sunlight. Awkward positioning; myself as interviewer, as reader. As I ask a question, I am alarmed by the ghoulish shrieks in the corridor, whistling and yelling, banging and running. The answers remind me, I have been here before. The answers are set right across from these words, tattered and scattered and thrown all around.

Our words are never our own / Our owned are never in words / We seep / Like air balloon rips / Like punctured bike tires / The blood is strip strewn / Like crab cooking screams / We breathe / And anthills are endlessly stepped on / Our language is like a machine / It breaks / Off into pieces / And puddles and poodles / And laughing hyenas and / Tiptoeing birds / That cackle cacophony / Coughing up words / And stringing the sentences / Stretched like a verb / Our words have a life / They are done, dead already

Along with Norman Klein (1997), who was writing in a much different context, "I look for ruptures more than coherence. I don't mind if the scenes fail to match, or the effects are uneven” (p. 9). These are shutters, stutters and gestures to meaning. The interpretation looks to desire. These words, of others and mine (both absent and present, present though absent), are engulfed in layers of transition and conversation, and in this movement "I like to sense the scars, perhaps where a cut was
I have no idea. I don’t know.

I don't know. I'll figure that out.

I guess it's challenging, 'cause you're going through things, but I mean, it's like anything else. Like, if you're middle-aged, you're going through things, if you're elderly, you're going through things, if you're a child, you're going through things, you know? I think it's just a pivotal time in your life, I guess, and yeah, I wouldn't say that there' $d$ be one thing to describe it, I guess, 'cause it's so varied, depending on who you are, as a person. I don't know, it can be hard at times, I guess, but it's intense, if anything, 'cause like everything is at extremes, I guess, like if you're very happy you're really, really happy. If you're stressed, you're very stressed. If you're having a hard time at home, you're having a really hard time at home. Everything's kind of in extremes.

I don't think I'm a typical high school student or teenager. I find that most, I don't know, I find that most, like other teenagers ... they're more rebellious than I am ... like they'll party, and stuff like that.

Complicated, if anything.

People stealing each other's friends, and fights about boyfriends, and it's just like ... it's childish, a little bit, and I know that it happens to everyone, I guess, like I've gotten into fights with my friends, it's just, 
made-objects removed during the chain of production, at different stages of participation” (Klein, p. 9). I ask for an offering. A movement towards. "The final version for me is only the survivor" (Klein, p. 9). There is so much lost in a transcribed text.

When interviewing, I sometimes lose all sense of awareness, and unexpectedly, my perception seems queerly clouded, like "a secret wound ... wandering” (Kristeva, 1991, p. 5). I am not sure what is happening, but learn to align myself with the words until I feel settled again. It is not a feeling of anxiety, but of slippage. There is a sense that I am weaving in and out of the present, and time itself feels somehow skewed. It is a dreamlike, reverie logic, similar to what her been described by Jane Gallop (2011) as "the logic of ghosts, the temporality of ghosts," which "allows something to be both persistent and vanishing” (p. 137). In these times I feel as a reader (A bad reader? An inattentive reader? A perverse reader?); moving on the page, yet moving past the page always. It is an uncanny reading that cannot be mapped - for de Certeau (1984), "the map cuts up" (p. 129) — and whose illegibility "evades textual archaeology" (Moller, 1991, p. 112). It is an uncanny reading that refuses to fasten, refuses to slacken. There is, in these fugitive moments, an "impossibility of establishing a clear distinction between the real and imaginary world" (p. 138). Though to be in such a place can be frightening, if we wonder, along with Phelan (1997), "why we long to hold bodies that are gone” (p. 3), such moments are also a reminder that we are never complete in ourselves, and that our bodies are always, to some extent, gone and shattered already. No body can "escape the time of its transience” (Heller-Roazen,
I don't know, I think you just have to take a step back sometimes, and be like, 'Really? Is this really what we're fighting about? Like, we're really fighting about who's wearing that shirt? Like, seriously? Is that really, in the grand scheme of things, is that what's really gonna matter to you?'

Because the way I read books is, like, each page I read I picture it as if it were a moment in my life, so I can't actually draw it down for you, but I can say that I use my brain, it's like out in the open, so I'm absorbing what I'm reading, but I'm also applying it to my own personal experience, as I'm reading.

Trust is a big thing in high school. Nobody has it for one another, like I have very, very few people that I truly trust. Same thing with teachers, administration, your parents. You don't want to trust anybody, because you feel like you're kind of isolated, alone, and you tell one person one thing, and before the day is over, the whole school knows. And why would you want that?

I don't like happy. Like, it has to be really, really depressing, and then happy. That's the kind of stuff ... it has to be a huge transition in their life, for me to actually enjoy it. There has to be a lot of ups and downs, too.

I was never really an emotional person. But I have a friend who's like super unstable with her emotions, and when she was younger, maybe in grade nine, she was everywhere. She'd be hysterical if 
2005, p. 45). Kristeva has described this experience well: 'I feel 'lost,' 'indistinct,' 'hazy.' The uncanny strangeness allows for many variations: they all repeat the difficulty I have in situating myself with respect to the other" (p. 187). This feeling is akin to encountering a demon dressed up in disguise - wearing your face, wearing your body, wearing your clothes, wearing your smile. It is only on closer inspection that we come to realize such shattering as an imperfect reflection, a mirrored self that demands battle. "The other is my unconscious” (Kristeva, p. 183).

As words mingle in speech, as we try to make them express what is always inexpressible, the path language takes is that of desire, and like all desires, its path is never straightforward, but follows what we may call a queer route. Within the matrix of a queer phenomenology - where there is much talk of lines, inheritances, tendencies, appearances, disappearances, shapings, slantings, straightenings, queerings, tracings, becomings, and facings-Sara Ahmed (2006a) has proposed that we challenge ourselves to revel, to "have joy" (p. 569), in effects of the uncanny where the familiar turns strange, to "find hope in what goes astray” (p. 570). In such straying and errant movement, Ahmed imagines every landscape as potentially queer; and in characterizing queer as that which is not straight, she references the concept of desire lines from theories of landscape architecture, which is "used to describe unofficial paths, those marks left on the ground that show everyday comings and going, where people deviate from the paths they are supposed to follow" (Ahmed, p. 570). In the ways that such tracings, such lines of rubbed ground, "cut across the formal grid ... risking disappointment and something bad would happen, she would go up the stairs and she would cry, and you just, you don't know how to contain everything that's going on in your head, and you feel like everything is so overwhelming, and that, kind of, stuff just piles on. Like, your parents are being assholes, assholes, or like, your school, like, the load is too much, and like, there's like stuff going on with your friends, so it piles up, and everything is so dramatic and chaotic in your head, that you don't know how to handle anything, so you kind of just, like you overreact, and do stuff you shouldn't be doing, just like ... because you don't know what's going on, and everything is so confusing.

They really want to shove it down our throats.

I don't think you're supposed to ever find yourself in life, and everyone talks about, 'When I'm older, I'll find myself.' ... People are in a constant state of change, and your personalities are kind of, I guess, malleable. I don't believe that people really are a constant, exactly.

They flow into one another, I guess.

Teachers. Oh, that's a good one ... They're either wonderful or they're terrible.

I was like so confused, I didn't know where to go, I was tiny, I was half the size I am now, I was just wandering around the school and didn't know what to do. 
destruction” (Hall, 2007, p. 287), there are desire lines in speech and writing as well, which echo unintended meanings, graspings, and pursuals. What do we risk when we speak a word? There is a hunting that is happening whenever we talk; there is a motion, a motive, and a movement.

Though its ephemeral nature often relegates such lines to a zone of exclusion, an area of error, I here want to conjure up what we might call a method an erroring: to dwell in "the space between the planned and the providential, the engineered and the 'lived', and between official projects of capture and containment and ... energies which subvert, bypass, supersede and evade them” (Shepherd \& Murray, 2007, p. 1).

As Ahmed (2004) has suggested, it is possible for pedagogical spaces - spaces of teaching, learning, and reading - to engage our capacity for wonder, to intentionally inhabit an unsure footedness in the face of unintended consequences and error. Wonder provides a space to compose impossible, 'as-if' questions. To read, 'as-if' you've never read before. To teach, 'as-if' you have no idea what you're teaching. To walk, 'asif' your body is broken, or you've come now new to it. To question, 'as-if' the answer could be anything in the world. For the space of the 'as-if,' things are startling and sudden. As a gesture towards such potential, these present columns of disparate writing allow for our readings to linger, and perform associations unintended between my own words and the transcribed words of others - cut-up, spliced and diced, these words form a strange, uncanny, and unruly architecture, through which we can read as a humbling walk.
I have to say, school is kind of killing education.

My mom, she doesn't understand why I read these types of books. I don't know, she says she finds them kind of useless, 'cause they're kind of girly, and a lot of times it's like fantasy, and a lot of that stuff doesn't really happen, in real life, so she doesn't really understand, but ...

And also, it's the words. I see numbers and they just go all over the place. ... But I see words, and it's fluid, it's what makes sense to me. So I guess it's my language. It works.

I feel like I look at these kids, and I'm like, I really hope I wasn't like that in grade seven, 'cause you're so loud, and you're running and you're like, "I don't know why you think this is okay," but then I kind of have like little flashbacks of when I was younger, and like ... I totally did that. 'Cause you're carefree, you don't care what people think about you. That's one of the good things about being a younger teenager, is you don't give a shit what people think about you, but then as you get older, you're more aware of your surroundings, and like ... what people might think of you, or how you're perceived. That kind of sucks. So when you're younger, it's better ... than when you're older. 


\section{Part 8: Echoed in the Margins}

Though-as mentioned above-de Certeau (1984) has asserted that "the map cuts up," he also noted that "the story cuts across" (p. 129), which signals the manner in which methods of textual architecture and practices of textual space can function to enable, or dis-enable, the sounding and resonance of particular narratives and interpretations. There is a constant play of emotional energies in reading experience, which invariably produces the text as an ambivalent site, and where it functions as a vessel, whose doubled meanings have been described by Bloomer (1993) as "both a container and a conduit, the sea and the ship. It is the thing disseminated and the instrument of dissemination. Vessels are

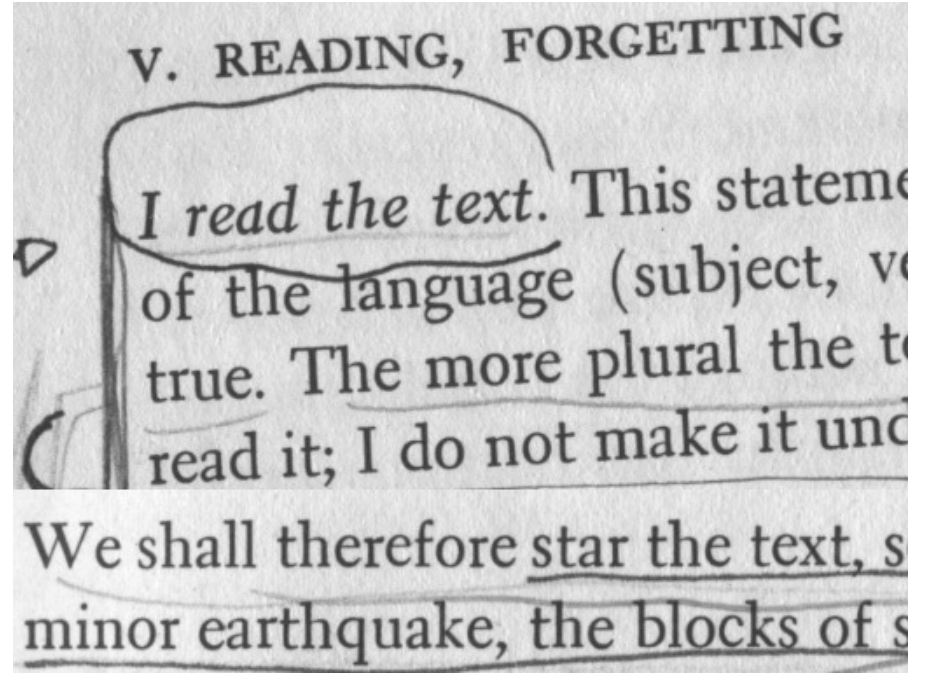
instruments in flux: through them flow information, oxygen, food, antibodies, semen” (p. 95). It is to these imprecise, epistemologically embodied movements of reader engagement that I now turn, and which can here be thought of in relation to the Kristevan semiotic - where "all is flux and incoherence, provisional, inchoate, occasional” (Ives, 1998, p. 97) but which also always persists within and through the boundaries of the symbolic, which in our present case refers to the stolid logic enmeshed in the material text. Such binaries intersect and interweave, signaling the fact that they are actually not binaries at all.

More particularly, I am talking about the oil-stained thumbprints in a library book, the dog-eared corners, the broken spines, the squiggles, the abstract theorizations, the curses in the margin, the highlighted phrases, the dirty limericks, and the underlined words. I am thinking through such marks and marginalia as an uncanny sign of life, a tenuously enduring presence of absent others, a sign of the body in reading, and a certain

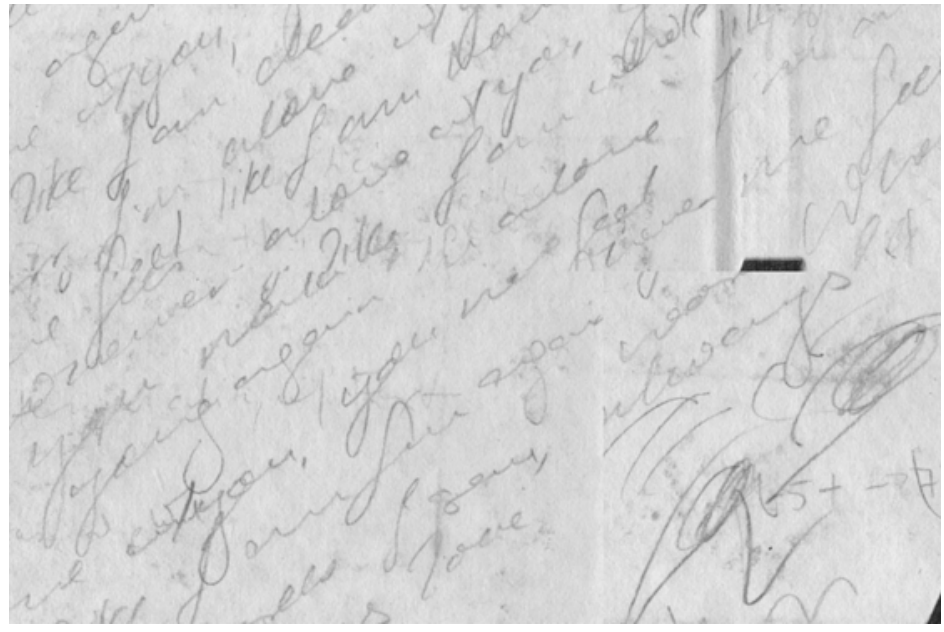
reminder of the reader; not you or me, the reader, but of other readers, assemblages and generations. Looking at the margins of library books, we are faced with "the space between the walls proper, the space of the joint" (Bloomer, 1993, p. 167), and thus the space where things can be taken productively and provocatively out of joint. Though the margins of a book are often regarded as a field of overdetermined emptiness, they 
are also breaches of form, and a place of potential fissure, on "the verge ... where something is about to happen” (Bloomer, 1993, p. 95).

However smudged and unreadable, the extra-textual trace is always a burden, a

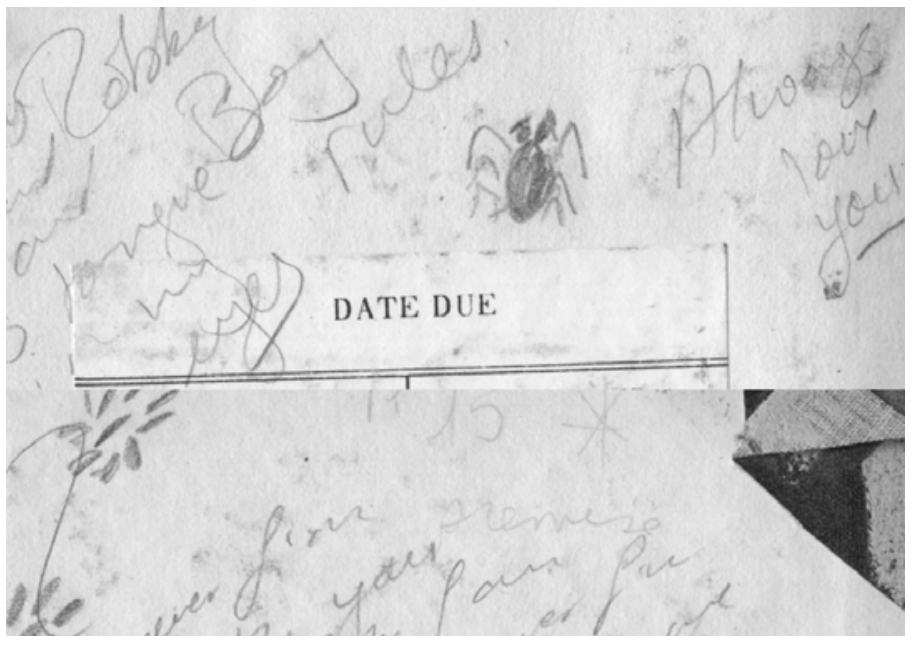
reminder of the inescapable existence of others, and of ourselves as an other. As space is taken up in the margin-and as it signifies the fact that space is really never blank at all, and that absolute absences, short of death, are impossible-there is an inevitable loss (of innocence, of any semblance of complete comprehension), though "it is often loss,” as Ahmed (2006b) has written, "that generates a new direction” (p. 19).

I was well into my Master's degree at the University of Ottawa, when I started running up against this thing called poststructuralist theory, and it all seemed so new and II Key 269 foreign to me, but foreign like a poem that you love despite an utter lack of understanding; the words threw me for a loop. I tended to immerse myself, bathe myself, humming the words, thinking such rapture would instill understanding. I checked out Roland Barthes' S/Z (1974) from the library, and I fell deeply in love with this "series of fragments" (Gallop, 2011, p. 33). There was a drive and a thrall in these words that moved me well, and I was apparently not the first to be so thrown. There was a unique type of "social evidence" (Dohlstrom, 2011, p. 116) in this particular copy of Barthes' book, which was filled with all types of marginalia, and which was just what I needed to experience at the time; a wordly performance that put "the notion and the boundaries of text to the test" (Dohlstrom, 2011, p. 124).

In my multiple encounters with this particular copy of Barthes' work, I could not help but read the author through these polyphonically-sounded scrawlings, which at times put his voice "literally in the background" (Dohlstrom, 2011, p. 126), and which made me "attentive to the regularities, norms and boundaries of our conceptions" (p. 128) of reading. Though I had no idea of the context of these anonymous musings, these scribbles of non-sense worked to unsettle my questions of sense and of place. As the limit-case pushes us to the brink of the sense of our readings, through which we can interrogate the 


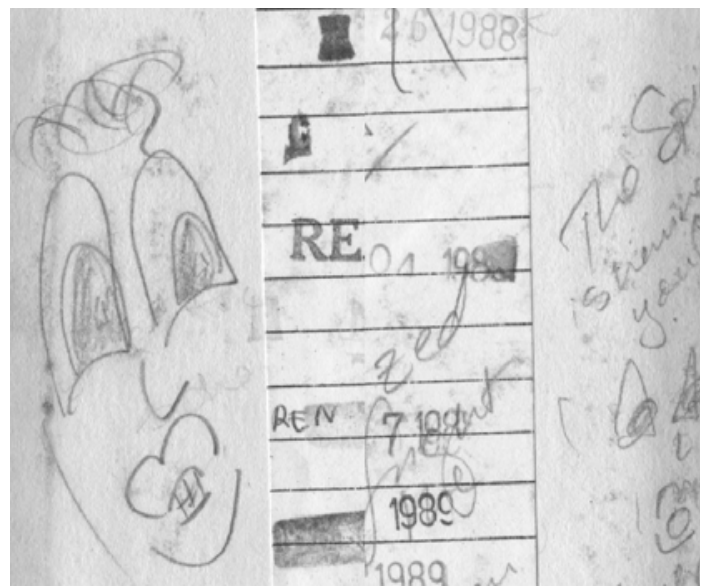

status of, or the privilege afforded to, the brink itself, I asked myself the question of who was allowed to speak in the act of reading, whose voice was the loudest, and how we could ever satisfactorily distinguish between such an "ear-splitting ... murmur of voices” (Dohlstrom, 2011, p. 123).

In her writing on the cultural meanings of marginalia in AngloCanadian cookbooks, which functioned in part as scrapbooks passed down through families, friends, and generations, Golick (2004) has noted that "the lowly cookbook without its marginalia is missing its soul" (p. 113), and it is interesting to note the use of the word "its," which here signals possession and ownership. The marginalia, unidentified and spectral, is illegitimate, namelessly remaindered, and owned by no one, and thus becomes owned by the book itself, an ownership which transforms the book into something that is markedly other than what it previously was: "a counterpart, an antithesis, or an anti-edition" (Dohlstrom, 2011, p. 125). To think on this copy of Barthes' text as a body of architecture, these graffitied

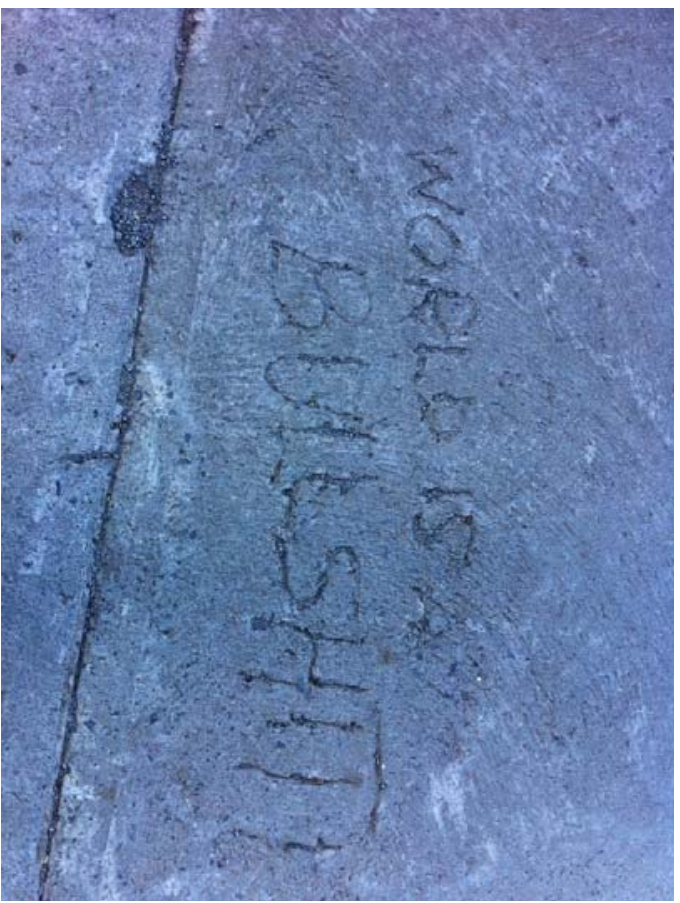
scribblings also operate as such, but as opposed to a body of structural and Cartesian logic that appears ideologically immovable, this is a "minor architecture," which has been described by Bloomer (1993)—with reference to Deleuze and Guattari-as "operat[ing] in the interstices of ... architecture. Not opposed to, not separated from, but upon/within/among: barnacles, bastard constructions ... An other writing upon the body" (p. 36). This is a type of tattoo, and a form of sidewalk scrawling (see the image to the left).

Coming back to this same text a few years after my initial encounter is a disconcerting experience, and I have to admit I am surprised that it is still in circulation. The spine is now broken, but the notes persist. Have they been added to? Have certain ones been removed? Which of them did I write myself? I am not sure, and it is this very hesitancy that allows me to understand the ways in which rereading can inform, and indeed, obscure, "what we are looking for now and what we have sought in the past" (Spacks, 2011, p. 242). To reread is to engage in the echoed life, and like the echo in a cave, it returns necessarily transformed, yet recognizable still. Such notions of repetition and displacement are at the heart of our 
discussions surrounding the uncanny: the troubling question of unintended repetition, the unknown extent of unavoidable displacement, the knowledge that something always remains, the uncontrollable mutability of memory, and the fact that we never read alone. Reading in (and through) the margins, as Irwin and O’Donoghue (2012) have described it, provokes in the reader an "openness," which leaves "traces of understanding rather than techniques, skills, methods and lessons” (pp. 227-228). While such "openness” may be uncertain and unreliable (a reader may hate, love, or find themselves confused in the face of such interventions), such is undeniably the case for all "realities ... for which there are no pre-existing models” (p. 227).

\section{Part 9: The Enigma of Now}

For epistemologies of teaching and reading to adequately encounter what de Lauretis (2008) has called "the enigma of now" (p. 4), we must first recognize that for the now to be read, we can only "sustain the impact of the real" (p. 9) in reworkings of our earlier experiences; and through reference to a type of double temporality that Freud has titled Nachträglichkeit, commonly referred to in English as deferred action, retroaction, or afterwardsness. In this formulation, the traumatic meaning of a repressed memory may remain silent until revived at a later date, and thus, as Freud (cited in de Lauretis, 2008) has written in Project for a Scientific Psychology, "a memory [can arouse] an affect which it did not arouse as an experience" (p. 7). For the purposes of this article, the implication here is that the fields of teaching and reading are forever populated by multiple species of memories, both meaning-full and meaning-less, interpretative terms whose suffixes remain threateningly ambivalent and disturbingly variable. Moreover, these are memories that, as Salvio (2007) has described, may "appear absent but take up an uncanny presence in our classrooms” (p. 19). If we think of our psyche as text, and thus as enmeshed in a circuit of reading, the process of articulating our subjectivity may be best understood as one of "self-translation, detranslation and retranslation" (de Lauretis, 2008, p. 120). This is, as de Lauretis (2008) has noted, “'an activity of production', a kind of text we weave and unweave in retranslating ourselves; a text ever in progress, with its plurality, its overdeterminations, its ongoing confrontation with the other” (p. 120). Such a text often does not make sense, and it is with an overarching knowledge of this potential non-sense-as a zone where meanings refuse to cohere-that I have shared these insignificant stories from my own experiences of teaching and reading.

Notably, when I write insignificant, I'm referring to the fact that of the stories I have here retold, not one has anything to do with the formal worlds of teaching: methods of evaluation, formulations of cross-curricular competencies, disciplinary strategies, lessons in essay writing, professional development, etc. Yet, the very insignificance of these stories alerts us to what Maxine Greene (2003) has called "the odd isolation of the teaching role" (p. x); the alienation that accrues in teaching, despite the fact that, as teachers, we are always surrounded by bodies. The problem is, we often do not know how to read through the text of passing experience as something meaningful, especially when a particular experience is thought of as trivial, fleeting, and ostensibly useless; and I am here thinking about the possibilities of reading in its most productive and creative sense - as with Pitt and Brushwood Rose (2007), this is "a problem of making emotional significance” (p. 329), and of recognizing the ways in which significance might be 
deferred. By focusing only on the immediately "educational" and observable, we run the risk of remaining emotionally and intersubjectively illiterate-our surroundings remain as alien, unapproachable, or unreadable.

Along with the obscure fact that those memories we forget are often of greater consequence than those we remember, I am thus here arguing towards a reassertion of the notion of insignificance in theories of teaching, learning, and reading, and that only through exploring the meaning of insignificant stories can we bear the terrible burden of the uncanny well-turn it into a readable thing (which again, does not imply surmountable). Though prison is certainly a different environment from school, Bernard Stiegler (2009) drew on his own experiences as a prisoner in describing the relation between significance and insignificance: "In prison, that which, today, is very prominent and consistent, laden with meaning and in that sense, 'significant,' never fails to become, tomorrow, indifferent, totally insignificant, and the very opposite of what it was" (p. 27). This understanding - that significance is in no way a permanent attribute-strips away from the object of study, whether experience or a piece of literature, the capacity for determining significance. Instead, this capacity rests squarely on the position of the person experiencing, remembering, or reading.

In further characterizing the insignificant, Stiegler (2009) proposed that:

There is nothing insignificant in itself, and that what can be insignificant are not the things themselves, or in themselves, but the relation I have or rather that I do not have with those things, such as I articulate and arrange them. (p. 27)

Along with Stiegler, then, I have considered in this article the importance of voicing insignificant stories, and that rather than insinuating a method that looks to the most memorable, the most notable of human experiences, I propose a practice of looking to the trivial, and arranging such experiences in a fashion that allows the reader to find "significance in the insignificant" (p. 27). When confronted with the uncanny, it is not, therefore, a matter of accepting the strangeness implied, but of positioning ourselves newly (and strangely) in relation to such strangeness, moving it in and out of significance. It is about working creatively with the uncanny, even as it does its work on us.

As the beast of experience is bloodied, his entrails removed and dragging behind, vomiting blood-as words-in a forward-like fashion, the least we can do is read in his body, see where the cuts and the blows have been placed, see what the form of his stumblings now take (and possibly, stop up or cut deeper a wound or two). As Kristeva (1991) has written, "A certain imbalance is necessary, a swaying over some abyss, for a conflict to be heard” (p. 17). When we feel weird in our teaching, we should, therefore, acknowledge such weirdness as a part of our job; we should name it, we should claim it, enduring the strangeness, and shouldering the fact that such strangeness will always remain — as akin to the playful attractions of a little fox terrier's love. 


\section{References}

Ahmed, S. (2004). The cultural politics of emotion. Edinburgh: Edinburgh University Press.

Ahmed, S (2006a). Orientations: Toward a queer phenomenology. GLQ: A Journal of Lesbian and Gay Studies, 12(4), 543-574.

Ahmed, S. (2006b). Queer phenomenology: Orientations, objects, others. Durham, NC: Duke University Press.

Barthes, R. (1974). S/Z. New York, NY: Hill and Wang.

Bloomer, J. (1993). Architecture and the text: The (s)crypts of Joyce and Piranesi. New Haven, CT: Yale University Press.

Britzman, D. P. (1998). Lost subjects, contested objects: Toward a psychoanalytic inquiry of learning. Albany, NY: State University of New York Press.

Britzman, D. P. (2003). Practice makes practice: A critical study of learning to teach, (Revised edition). Albany, NY: State University of New York Press.

Britzman, D. P. (2011). Freud and education. New York, NY: Routledge.

Brooks, P. (1982). Freud's masterplot: Questions of narrative. In S. Felman (Ed.), Literature and psychoanalysis: The question of reading: Otherwise (pp. 280-300). Baltimore, MD: The Johns Hopkins University Press.

Casemore, B. (2008). The autobiographical demand of place: Curriculum inquiry in the American South. New York, NY: Peter Lang.

de Certeau, M. (1984). The practice of everyday life (S. Randall, Trans.). Berkeley, CA: University of California Press.

de Lauretis, T. (2008). Freud's drive: Psychoanalysis, literature and film. New York, NY: Palgrave Macmillan.

Déry, T. (2009). Niki, the story of a dog (M. Secker, Trans.). New York, NY: The New York Review of Books. (Original published in 1956)

Dohlstrom, M. (2011). A book of one’s own: Examples of library book marginalia. In R. Crone, \& S. Towheed (Eds.) The history of reading: Methods, strategies, tactics (Vol. 3, pp. 115-131). New York, NY: Palgrave Macmillan.

Farley, L. (2009). “Invisible ink”: A psychoanalytic study of school memory. Bank Street Occasional Paper Series, 22, 17-23.

Freud, S. (2003). The Uncanny. In D. McLintock (Trans.) and A. Philips (Ed.), The Uncanny (pp. 123-162). London, UK: Penguin. (Original published in 1919)

Gallop, J. (2011). The deaths of the author: Reading and writing in time. Durham, NC: Duke University Press. 
Gee, J. P. (2004). Sociolinguistics and literacies: Ideology in discourses. London, UK: Routledge.

Golick, G. (2004). “one quart milk, five eggs I should say”: Marginalia in Anglo-Canadian cookbooks. Variants: The journal of the European Society for Textual Scholarship (23), 95-113.

Greene, M. (2003). Foreword. In D. Britzman, Practice makes practice: A critical study of learning to teach, (Revised ed., pp. ix-xi). Albany, NY: State University of New York Press.

Hall, M. (2007). Afterword: Lines of desire. In N. Murray, N. Shepherd, \& M. Hall (Eds.) Desire lines: Space, memory and identity in the post-apartheid city (pp. 287-298). London, UK: Routledge.

Hamsun, K. (2008). Hunger.(R. Bly, Trans.). New York, NY: Farrar, Strauss, and Giroux. (Original published in 1890)

Heller-Roazen, D. (2005). Echolalias: On the forgetting of language. New York, NY: Zone Books.

Irwin, R. L., \& O’Donoghue, D. (2012). Encountering pedagogy through relational art Practices. IJADE: International Journal of Art and Design Education, 31(3), 221-236.

Ives, K. (1998). Julia Kristeva: Art, love, melancholy, philosophy, semiotics and psychoanalysis. Maidstone, UK: Crescent Moon Publishing.

King, A. E. (2011). Hating everything: A coming-of-age graphic narrative. Girlhood Studies, $4(1), 67-94$.

Klein, N. M. (1997). The history of forgetting: Los Angeles and the erasure of memory. New York, NY: Verso.

Kristeva, J. (1991). Strangers to ourselves (L. S. Roudiez, Trans.). New York, NY: Columbia University Press.

Lacan, J. (1991). The seminar of Jacques Lacan: Book II, The ego in Freud's theory and in the technique of psychoanalysis, 1954-1955 (J-A. Miller, Trans.). New York, NY: W.W. Norton.

Lawrence-Lightfoot, S. (2003). The essential conversation: What parents and teachers can learn from each other. New York, NY: Random House.

Mitchell, C., Strong-Wilson, T., Pithouse, K., \& Allnut, S. (2011). Introducing memory and pedagogy. In C. Mitchell, T. Strong-Wilson, K. Pithouse, \& S. Allnut (Eds.) Memory and pedagogy (pp. 1-16). New York, NY: Routledge.

Miller, J. (2004). Sounds of silence breaking: Women, autobiography, curriculum. New York, NY: Peter Lang.

Moller, L. (1991). The Freudian reading: Analytical and fictional constructions. Philadephia, PA: University of Pennsylvania Press. 
Ng-A-Fook, N. (2012). Navigating m/other-son plots as a migrant Act: Autobiography, currere, and gender. In S. Springgay and D. Freedman (Eds.), M/othering a bodied curriculum (pp. 160-185). Toronto, ON: University of Toronto Press.

O’Loughlin, M. (2009). The subject of childhood. New York, NY: Peter Lang Publishing.

Phelan, P. (1997). Mourning sex: Performing public identities. London, UK: Routledge.

Phillips, A. (1995). Terrors and experts. Cambridge, MA: Harvard University Press.

Pinar, W. F. (1994). Autobiography, politics and sexuality: Essays in curriculum theory. New York, NY: Peter Lang.

Pinar, W. F., \& Grumet, M. (1976). Toward a poor curriculum. Dubuque, IA: Kendall/Hunt.

Pitt, A. J., \& Brushwood Rose, C. (2007). The significance of emotions in teaching and learning: On making emotional significance. International Journal of Leadership in Education, 10(4), 327-337.

Robertson, J. P. (1994). Cinema and the politics of desire in teacher education. Unpublished doctoral dissertation, University of Toronto, Toronto, ON, Canada.

Robertson, J. P. (2001). What happens to our wishes: Magical thinking in Harry Potter. Children's Literature Association Quarterly, 26(4), 198-211.

Said, E. (1985). Beginnings: Intention and method. New York, NY: Columbia University Press.

Salvio, P. (2007). Anne Sexton: Teacher of weird abundance. Albany, NY: State University of New York Press.

Shepherd, N., \& Murray, N. (2007). Introduction: Space, memory and identity in the postapartheid city. In N. Murray, N. Shepherd, \& M. Hall (Eds.) Desire lines: Space, memory and identity in the post-apartheid city (pp. 1-18). London, UK: Routledge.

Spacks, P. M. (2011). On rereading. Cambridge, MA: Harvard University Press.

Stiegler, B. (2009). Acting out (D. Barison, D. Ross, \& P. Crogan, Trans.). Stanford, CA: Stanford University Press.

Taussig, M. (1992). The nervous system. New York, NY: Routledge.

Thurschwell, P. (2009). Sigmund Freud: Second edition. New York, NY: Routledge.

\section{Endnote}

${ }^{1}$ As parts of this paper use autobiographical writing as a way to question the internal dynamics at play in curriculum, this article follows in the tradition of numerous curriculum scholars-such as Casemore (2008); Miller (2004); Ng-A-Fook (2012); Pinar (1994); and Pinar and Grumet (1976), among others—who have worked with autobiographical writing as a way to provoke "a curriculum-lived-as-migrancy, one in continual transit, of departing, returning, thinking back, and writing forward” (Ng-A-Fook, 2012, p. 181). 